\title{
Echinuria uncinata (Rudolphi) (Nematoda, Acuariidae) in Netta peposaca (Vieillot) (Aves, Anatidae) in South America ${ }^{1}$
}

\author{
Eliane F. da Silveira ${ }^{2,3}$; José F. R. Amato ${ }^{2} \&$ Suzana B. Amato ${ }^{2}$ \\ ${ }^{1}$ Contribution number 476 of the Departamento de Zoologia, Universidade Federal do Rio Grande do Sul. \\ 2 Departamento de Zoologia, Instituto de Biociências, Universidade Federal do Rio Grande do Sul. Caixa Postal 15014, \\ 91501-970 Porto Alegre, Rio Grande do Sul, Brasil.E-mail: jfamato@terra.com.br; sbamato@ufrgs.br \\ ${ }^{3}$ Departamento de Biologia, Museu de Ciências Naturais, Universidade Luterana do Brasil. 92425-900 Canoas, Rio Grande \\ do Sul, Brasil.E-mail: labinvertebrados@ulbra.tche.br
}

\begin{abstract}
This is the first report of a species of Echinuria Soloviev, 1912, on anatid hosts in South America, causing granulomas. It is also the first detailed description and record of a species of Echinuria, for South America in the Rosy-billed Pochard, Netta peposaca (Vieillot, 1816). Fifty-two rosy-billed pochards were examined for helminths in the Municipalities of Santa Vitória do Palmar (locality of Fazenda Sossego) and (locality of Ponta da Antena), State of Rio Grande do Sul, Brazil, and Alvear, Province of Corrientes, northern Argentina. Samples were obtained from 2003 to 2004. After the catch each bird was immediately frozen with dry ice. Prior to necropsy birds were sexed, weighted, measured, and the state of maturity (juvenile or adult) determined, based on the presence or absence of a bursa of Fabricius. The granulomas with the nematodes were found in the proximal esophagus at the junction with the proventriculus. Two birds had one (fistulated) and two granulomas, respectively. One of the birds was from the wintering grounds along the coastal region in the State of Rio Grande do Sul, southern Brazil. The other, from one of the breeding grounds in northern Argentina, was captured before the trip to the wintering grounds along the migratory flyway. Prevalence was $3.8 \%$ while the mean intensity of infection was 7.2. Morphometry of males and females and the comparison with previous descriptions and illustrations allowed the identification of the present specimens as $E$. uncinata.

KEY WORDS. Breeding grounds; granuloma; migratory flyway; northern Argentina; rosy-billed pochard; southern Brazil; wintering grounds.
\end{abstract}

RESUMO. Echinuria uncinata (Rudolphi) (Nematoda, Acuariidae) em Netta peposaca (Vieillot) (Aves, Anatidae) na América do Sul. Este é o primeiro registro de uma espécie do gênero Echinuria Soloviev, 1912, em hospedeiros anatídeos na América do Sul, causando granulomas. É, também, a primeira descrição detalhada e o primeiro registro de Echinuria uncinata (Rudolphi, 1819) Soloviev, 1912, para a América do Sul, e o primeiro registro de um nematóide acuarióideo em Netta peposaca (Vieillot, 1816). Cinqüenta e dois marrecões foram examinados para helmintos nas localidades de Fazenda Sossego e Ponta da Antena, Município de Santa Vitória do Palmar, Estado do Rio Grande do Sul, região Sul do Brasil e Alvear, Província de Corrientes, região Norte da Argentina. As amostras foram obtidas no período de 2003 a 2004. Imediatamente após o abate, cada ave foi congelada em gelo seco. As aves foram separadas por sexo, pesadas e medidas. $O$ estado de maturidade de cada ave foi avaliado (juvenil ou adulto) com base na presença ou ausência da bolsa de Fabricius. Os granulomas, contendo os nematóides, estavam situados na base do esôfago quase junto à junção com o proventrículo. Duas aves estavam positivas, com um (fistulado) e dois granulomas, respectivamente. Uma das aves era proveniente do Brasil (pólo de invernia na planície costeira do Estado do Rio Grande do Sul). A outra da região Norte da Argentina, capturada em um dos pólos de nidificação, antes de empreender sua viagem em direção à costa brasileira ao longo de sua rota de migração. A prevalência da infecção foi de 3,8\% e a intensidade média de infecção de 7,2. A morfometria de machos e de fêmeas permitiu a identificação dos espécimes como $E$. uncinata. PALAVRAS-CHAVE. Granulomas; marrecão; norte da Argentina; pólo de invernia; pólo de nidificação; rota de migração; sul do Brasil.

Echinuria Soloviev, 1912 contained several species originally described in other genera that did not comply with a clear generic diagnosis of possessing two rows of spines along each lateral side. Cram (1927) made a comprehensive study of 
the nematode parasites of birds in the "suborders Strongylata, Ascaridata, and Spirurata", presenting a key for the 13 species of Echinuria known to that date. Eight of these species, including three which had originally been described by Molin in the mid 1860's from two Brazilian hosts, were transferred to the genus, becoming new combinations. One species was described as new. Cram (1927) still retained in Echinuria species which later were transferred, manly to the genus Syncuaria Gilbert, 1927. Echinuria parva was added to the list by CrAm (1928).

Chitwood \& WeHr (1934) synonymized Syncuaria with Echinuria as their cordons were similar. Echinuria was revised at the time of the proposition of the new subfamily Echinuriinae Sobolev, 1943. Echinuria uncinata (Rudolphi, 1819) Soloviev, 1912 is a nematode parasite of anatid birds and the most commonly found species of the genus. It has been found associated to granulomas, in the esophagus, proventriculus, gizzard, and sometimes, the small intestine, in different parts of the world. Mortalities of wild and domestic birds have been associated to a high intensity of infection by this species and to its high pathogenicity. The other species, apparently, were found only on the occasion in which they were first described.

BuxTon et al. (1952) conducted experiments with ducks in a small lake in Great Britain and described the granulomas found in the proventriculus and their relationship to the physical condition of the dead birds. GIBSON \& BARNES (1957) reported an outbreak of echinuriosis in domestic geese and ducks in the United Kingdom, showing the granulomas scattered over the surface of the proventriculus. CoRNwell (1963) worked with three species of anatids in southern Manitoba, Canada, describing the lesions and the physical alterations inflicted to the hosts by E. uncinata. The author linked the peak of bird mortality to the occurrence of drought in the areas of high concentration of birds; drought causing a high concentration of Daphnia spp. specimens (the intermediate host) in small lakes, thus increasing the chance for bird infection.

BEZUвік (1956) briefly described and partially illustrated specimens of $E$. uncinata from several anatid hosts in Poland. Other papers have been published on parasites of anatids, where E. uncinata was listed: Lalitha \& Alwar (1960), CHANDRASEKHARAN \& Peter (1969), and Lone et al. (1971) in India; JANSEN JR. \& VAN DEN Ввоек (1963) in the Zoological Garden of Copenhagen, Denmark; Avery (1966a) in a species of the genus Netta Kaup, 1829 and Avery (1966b) both in the UK; George \& Bolen (1975) in southern Texas, USA; and Zuchowska (1997) in Poland. Previously, Zuchowska (1970) had found 32\% of the waterfowl species at the Lodz Zoo infected with E. uncinata and that $16 \%$ of the cases resulted in death. These reports did not include descriptions or illustrations which could allow the species confirmation.

Austin \& Welch (1972) recorded the presence of E. uncinata in Canada. These authors described the life cycle and the larval stages found in several species of crustaceans collected from the wild, as well as in the laboratory, in addition to test several crustacean species as possible intermediate hosts. The lesions found in the waterfowl at Delta, Manitoba were described and experiments were conducted with several species of anatids to determine their susceptibility to E. uncinata. Ould \& Welch (1980) studied the influence of stress on infected anatids in Canada. It was observed that stressed ducks were infected with larger size nematodes and had a higher intensity of infection. Recently, Work et al. (2004) recorded a high degree of mortality among Laysan duck populations (Anas laysanensis Rothschild, 1892) in Laysan Island, Hawaii, due to E. uncinata.

FARIAS \& CANARIS (1986) recorded E. uncinata in the Mexican duck, Anas platyrhynchos diazi Ridgway, 1886, from North Central Mexico and the southwestern United States, while FedYNich et al. (1996) recorded the presence of E. uncinata in the only helminth community structure and pattern study of two allopatric populations of Anas fulvigula Ridgway, 1874, conducted on a nonmigratory waterfowl species in North America.

The external morphology of E. uncinata has been described by KENNEDY et al. (1973). These authors gave details about the cordons and the body spines, as well as the possible functions of both, based on optical and scanning electron microscopy (SEM). Clark $(1977,1979)$ recorded the presence of $E$. uncinata and described a new species, Echinuria australis Clark, 1979, from Anas superciliosa Gmelin, 1789 of New Zealand, respectively. The author has indicated the smaller size of E. australis as one of the key characters for its differentiation from other species in the genus, comparing it to E. uncinata.

Vicente et al. (1995) listed three species of Echinuria described by Molin in the mid 1800's as occurring in Brazil, because, apparently, they did not see the work of Wong et al. (1986) who transferred two of these species from Echinuria to Syncuaria and the third to Desportesius (Chabaud \& Campana) Skrjabin, Sobolev \& Ivashkin, 1965.

The present paper is the first record of a species of Echinuria causing granulomas on any anatid host in South America; the first detailed description of a species of Echinuria, from South America; and the first record of E. uncinata (extending its known geographical distribution) to the South American continent. This is the first record of acuarioid nematodes in the Rosy-billed Pochard, Netta peposaca (Vieillot, 1816).

\section{MATERIAL AND METHODS}

Fifty-two rosy-billed pochards ( $N$. peposaca), known in Brazil as 'marrecão', were captured by shot gun, with permission of the Instituto Brasileiro do Meio Ambiente e Recursos Naturais Renováveis (IBAMA) (license $N^{\circ} 042 / 2004 / R S$ ) in the Municipalities of Santa Vitória do Palmar (3316 $13^{\prime \prime}$, $\left.053^{\circ} 26^{\prime} 28^{\prime \prime} \mathrm{W}\right)$ - locality of Fazenda Sossego and ( $33^{\circ} 04^{\prime} 03^{\prime \prime} \mathrm{S}$, $\left.053^{\circ} 19^{\prime} 20^{\prime \prime} \mathrm{W}\right)$ - locality of Ponta da Antena, State of Rio Grande do Sul, southern Brazil, and Alvear (29 09'13"S, 056 $\left.54^{\prime} 34^{\prime \prime} \mathrm{W}\right)$, Province of Corrientes, northern Argentina. Samples were obtained from 2003 to 2004 . Each host was immediately frozen with dry ice. Prior to necropsy birds were sexed, weighted, measured, and had the state of maturity (juvenile or adult) deter- 


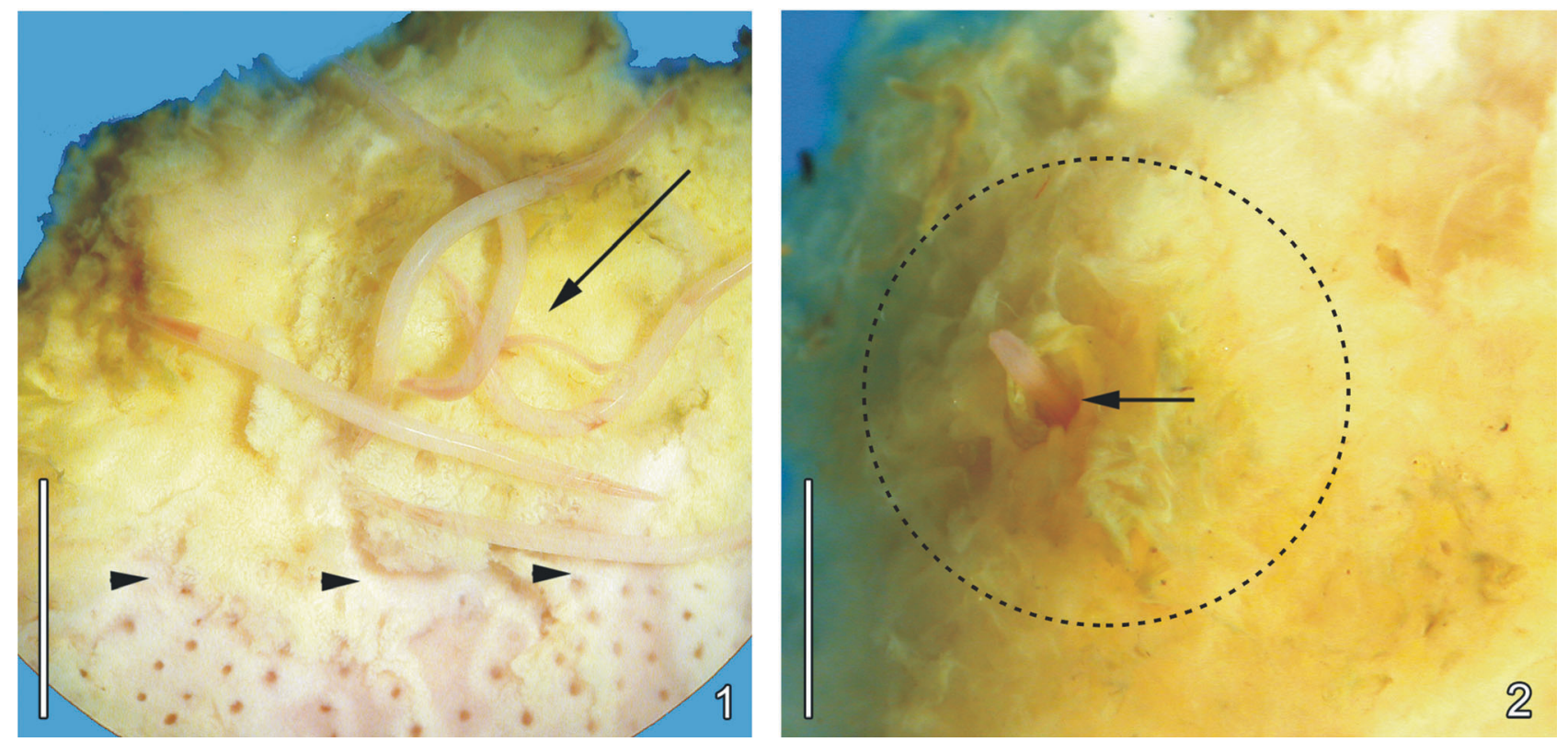

Figures 1-2. Granulomas caused by Echinuria uncinata: (1) specimens over the granuloma in the proximal esophagus, bordering proventriculus (head arrows), bar $=5 \mathrm{~mm}$; (2) granuloma showing a nematode protruding from fistula (dashed circle shows the limits of the granuloma), bar $=5 \mathrm{~mm}$.

mined, based on the presence or absence of a bursa of Fabricius. Nematodes were fixed in $65^{\circ}$ C A.F.A. (Амато et al. 1991), cleared in lactophenol (HuMASON 1972), and mounted in Canada balsam. Spicules were removed with fine needles and mounted in deFaure's (deF) medium (Амато et al. 2003). Measurements are in micrometers $(\mu \mathrm{m})$ unless otherwise indicated; ranges are followed (between parentheses) by the mean \pm the standard deviation values, and the number of specimens measured for a given character (when different than the stated number measured). Ecological concepts were used according to BusH et al. (1997). Photomicrographs were taken with a Zeiss Axiolab microscope equipped with phase contrast or with a Leica DMR Hc differential interference contrast (DIC) microscope with Nomarski's prisms. Duck carcasses were deposited in the Coleção Ornitológica do Museu de Ciências Naturais da Fundação Zoobotânica do Rio Grande do Sul (MCN), Porto Alegre, Rio Grande do Sul, Brazil. Helminth voucher specimens were deposited in the Coleção Helmintológica do Instituto Oswaldo Cruz (CHIOC), Rio de Janeiro, RJ, Brazil.

\section{RESULTS}

\section{Echinuria uncinata (Rudolphi, 1819) Soloviev, 1912 Figs $1-26$}

Description. Body slender, attenuated at extremities. Females larger than males (proportion of 1.3: 1). Anterior end round, with two projecting pseudolabia (Figs 3 and 10), one amphidial pore, and two cephalic papillae on each side. Two pairs of not recurrent but anastomosing cordons (Figs 3-6) arising from the pseudolabia, in the sides of the body, in average, $5.9 \%$ of total body length (TBL), in both sexes. Cordons formed by individual plates, with a central canal (Fig. 5). Deirids small (Fig. 6), at level of nerve ring, between cordons and first two spines of each row of body spines. Cuticle with fine striations (Figs 12 and 21) and four longitudinal, mostly parallel, lateral rows of spines, swinging to dorsal region between lateral ventral cordons (Figs 3 and 4), at level of nerve ring and meeting almost at posterior tip of body (Fig. 21). Spines change slightly in shape along body length; as well as cuticle texture between spine rows (Figs 6-9); at middle region of body the base narrows and tips are slightly curved, with the cuticle showing raised fine texture (Fig. 7); in posterior region spines have wider base and straight tip with cuticle showing more conspicuous texture (Fig. 8); spine length (tip to base) (Fig. 9) 30-42.5 ( $\bar{x}=37.5$ \pm 3.82 ). Excretory pore difficult to observe, located between cordons and posterior portion of nerve ring, just below level of cordon anastomosis. Buccal capsule long, with transversally striated cuticle (Fig. 10), and valve or sphincter at union with esophagus (Fig. 10). Nerve ring in narrower, anterior portion of muscular esophagus (Fig. 11). Muscular esophagus varying from 5.8 to $7.5 \%$ of TBL; glandular esophagus varying from 12 to $15 \%$ of TBL.

Males $(\mathrm{n}=7)$. Males smaller than females, 9.4-12.7 mm $(\bar{x}=10.91 \mathrm{~mm} \pm 1.30)$ long, 300-400 $(\bar{x}=35 \pm 30)$ wide. Cordons $580-730(\bar{x}=644.29 \pm 58.27)$ long, corresponding to $5.9 \%$ of TBL and $67 \%$ of the added buccal capsule and muscular

\section{Revista Brasileira de Zoologia 23 (2): 520-528, junho 2006}



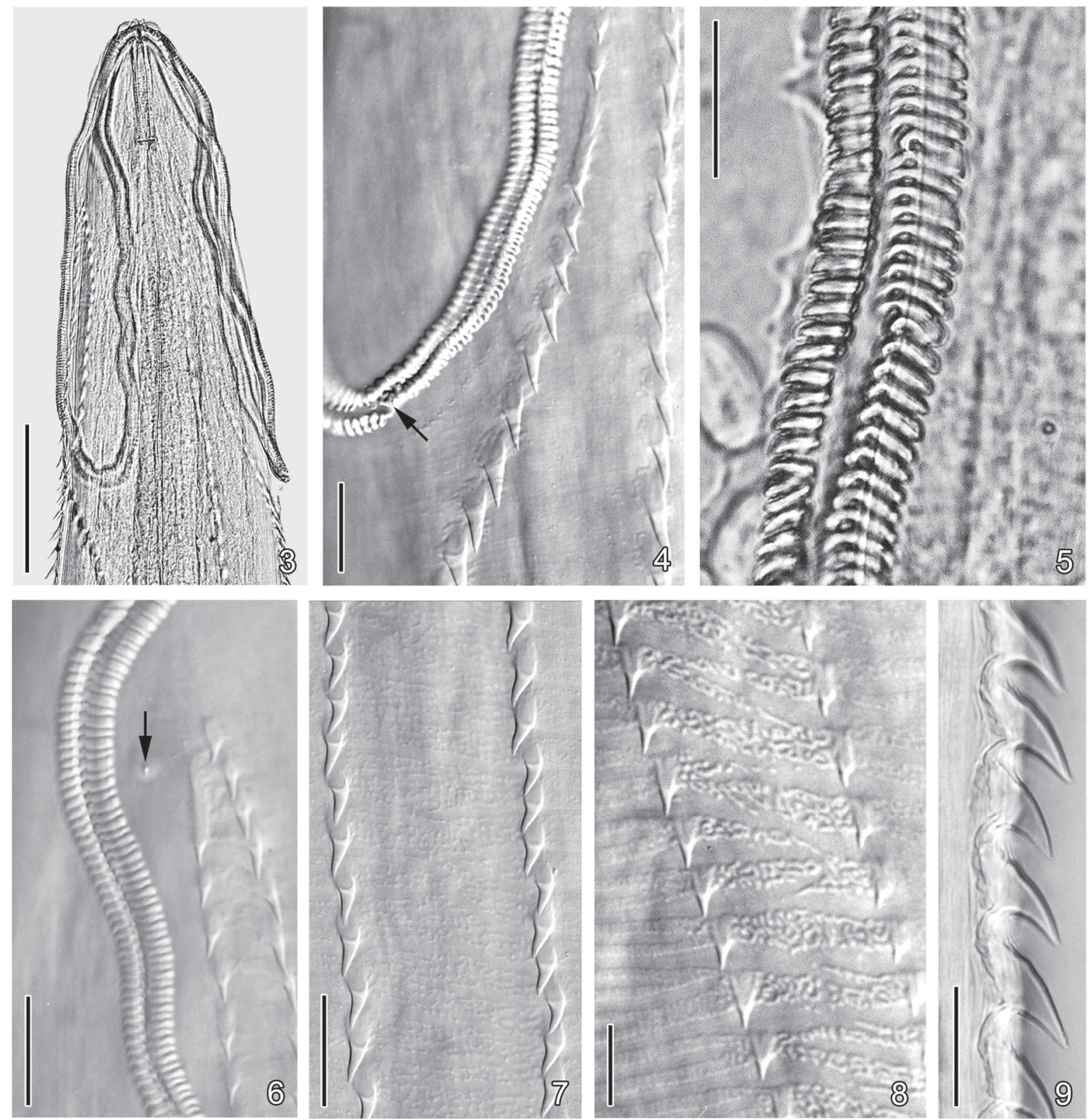

Figures 3-9. External morphology of Echinuria uncinata: (3) anterior region, showing the lateral ventral cordons and the four lateral rows of spines, bar $=200 \mu \mathrm{m}$; (4) point of cordon anastomosis (arrow) and the lateral rows of spines reaching the dorsal side of body, over the cordons (DIC), bar $=50 \mu \mathrm{m}$; (5) higher magnification of the plates which form the cordons showing the central canal, bar = $25 \mu \mathrm{m}$; (6) deirid (arrow) located at the level of first two spines, between the cordon and the beginning of the double rows of cuticular spines (DIC), bar = $50 \mu \mathrm{m}$; (7 and 8) the double row of cuticular spines (DIC), (7) anterior region of the body showing the shape of spines and the fine texture of cuticle, $b a r=50 \mu \mathrm{m}$, (8) mid-region of body showing the irregular, coarser texture of cuticle between the rows of cuticular spines, bar $=25 \mu \mathrm{m}$; (9) cuticular spines in lateral view, bar $=50 \mu \mathrm{m}$.

esophagus lengths, respectively. Buccal capsule 122.5-135 $(\bar{x}=127.79 \pm 4.58)$ long; muscular esophagus $730-1000$ $(\bar{x}=822.86 \pm 96.04)$ long; glandular esophagus $2.1-2.28 \mathrm{~mm}$ $(\bar{x}=2.2 \mathrm{~mm} \pm 79.87 ; \mathrm{n}=5)$ long. Nerve ring in anterior portion of muscular esophagus, $225-250(\bar{x}=234.6 \pm 9.41 ; n=6)$ from anterior extremity. Posterior region of body curved ventrally (Fig.

Revista Brasileira de Zoologia 23 (2): 520-528, junho 2006 


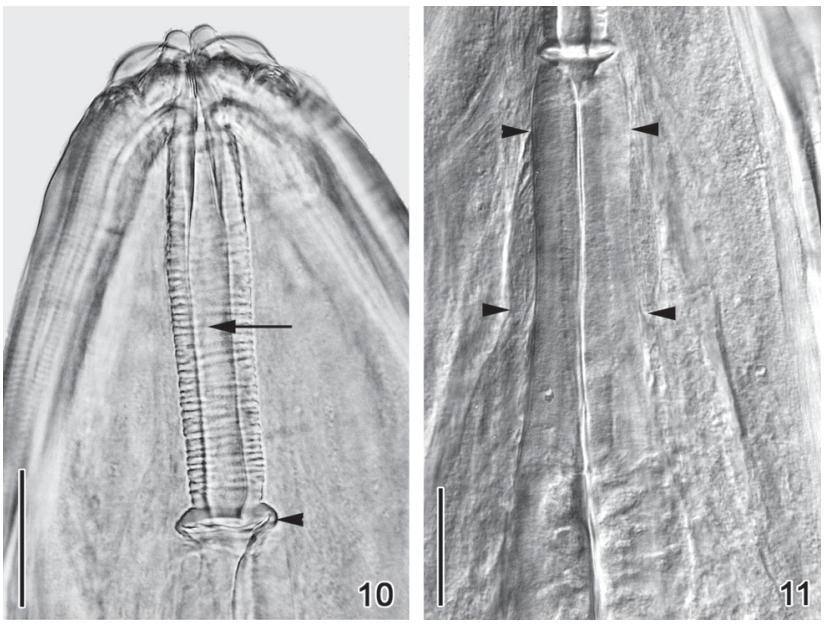

Figures 10-11. Anterior region of Echinuria uncinata: (10) pseudolabia and striated buccal capsule (arrow), with a valve or sphincter at union with esophagus (head arrow) (DIC), bar $=50$ $\mu \mathrm{m}$; (11) anterior region of the muscular esophagus showing the nerve ring (limits pointed by head arrows) (DIC), bar $=50 \mu \mathrm{m}$.

12). Tail $350-540(\bar{x}=431.7 \pm 71.32)$ long; four pairs of precloacal, pedunculated papillae and five pairs of sessile, post-cloacal papillae, of which, the first two pairs are close together (Fig. 12); tip of tail with button-like process. Spicules hollow, dissimilar, unequal (Fig. 12); right spicule wider (Fig. 13), widest at center, $205-250(\bar{x}=224.6 \pm 19.5)$ long; proximal region with fine spine-like projections (Fig. 13); distal portion with a typical, specific, transparent membrane (Fig. 14) and two conical or spikelike projections, one proximal, larger, another distal, smaller (Fig. 14); left spicule slender, 550-725 ( $\bar{x}=669.25 \pm 58.57$ ) long; proximal end bell-shaped (Figs 15 and 16), distal end flared, with three or four points supporting thin-walled, open funnel-like tip (Figs 17-19); length of right /left spicules ratio 1: 2.2-3.41.

Females $(n=8)$. Females didelphic, prodelphic, larger than males, $12.7-15.6 \mathrm{~mm}(\overline{\mathrm{x}}=14.3 \mathrm{~mm} \pm 0.9)$ long; maximum width $700-900(\bar{x}=800 \pm 10)$. Cordons $780-950(\bar{x}=856 \pm 69.1)$, as in males, covering $5.9 \%$ of TBL and $78.2 \%$ of added buccal capsule and muscular esophagus lengths. Buccal capsule 105-150 $(\bar{x}=133.2 \pm 16.2)$ long; muscular esophagus $810-1120$ $(\bar{x}=961.5 \pm 114.4 ; n=5)$ long; glandular esophagus 1.23-2.21 $\mathrm{mm}(\overline{\mathrm{x}}=1.78 \mathrm{~mm} \pm 0.5 ; \mathrm{n}=3)$ long. Nerve ring 257.5-312.5 $(\bar{x}=293.3 \pm 31.1 ; n=3)$ from anterior extremity. Vulva in posterior region of body (Figs 20 and 23), at some distance from the anus, distant $1.11-1.95 \mathrm{~mm}(\overline{\mathrm{x}}=1.38 \mathrm{~mm} \pm 0.26)$ from posterior extremity; $1.2-1.72 \mathrm{~mm}(\overline{\mathrm{x}}=1.33 \mathrm{~mm} \pm 0.19 ; \mathrm{n}=6)$ distant from anus (Fig. 20), with thick, ring-like border, which might keep it open (Fig. 25); vagina short (Fig. 24), with thick walls (Figs 23 and 24), receiving both uteri from the front of the body (Fig. 23); eggs elliptical, thick-shelled (Fig. 25), 31.3$33.3(\bar{x}=32.3 \pm 1.0)$ long, $19.5-21.3(\bar{x}=20.3 \pm 0.8)$ wide, some- times larvated. Anus is a horizontal slit (Fig. 22), with 'thickenings' anteriorly (Fig. 22). Tail short, conical, with tip rounded (Fig. 21), 210-300 ( $\bar{x}=261.3 \pm 34)$ long.

Granulomas. Two birds had one (fistulated - Fig. 2) and two granulomas (Figs 1 and 2), respectively, in the proximal portion of the esophagus, contiguous to the proventriculus (Fig. 1). The nodules measured approximately $8 \mathrm{~mm}$ in diameter. All nematodes were removed from the nodules, but one specimen, which was free in the lumen of the proventriculus.

Synonyms. Spiroptera uncinata Rudolphi, 1819; Dispharagus uncinatus (Rudolphi, 1819) Railliet, 1893; Acuaria (Hamannia) uncinata (Rudolphi, 1819) Railliet, Henry \& Sisoff, 1912; Hamannia uncinata (Rudolphi, 1819) Stiles \& Hassall, 1920.

Host. Netta peposaca (Vieillot, 1816) - new host record (NHR).

Host specimens deposited. MCN Nos 2775 - male; 2776 female.

Localities. Fazendas Sossego and Ponta da Antena, Municipality of Santa Vitória do Palmar, State of Rio Grande do Sul, southern Brazil, and Alvear, Province of Corrientes, northern Argentina.

Site of infection. Proximal esophagus, almost at the junction with the proventriculus, within granulomas, one of them fistulated.

Prevalence. $3.8 \%$.

Mean intensity of infection. 7.2.

Voucher specimens deposited. CHIOC Nos 36.627 - female; 36.628 - male.

\section{DISCUSSION}

Wong et al. (1986), in a revision of Syncuaria, transferred, based on type specimen examinations, four species which were incorrectly placed in Echinuria: Syncuaria leptoptili (Gedoelst, 1916) Sobolev, 1943; Syncuaria hargilae (Baylis \& Daubney, 1923) Sobolev, 1943; Syncuaria squamata (Linstow, 1883) Wong, Anderson \& Bartlett, 1986; and Syncuaria decorata (Cram, 1927) Wong, Anderson \& Bartlett, 1986. Two additional species (collected in Brazil) were considered as species inquirendae: Syncuaria calcarata (Molin, 1860) Sobolev, 1943, from Aramus guarauna guarauna (Linnaeus, 1766) (= Ibis guarauna) and Syncuaria longeornata (Molin, 1860) Skrjabin, Sobolev \& Ivashkin, 1965, from Ciconia maguari (Gmelin, 1789). The third species collected in Brazil, which Molin, in the mid 1860's, described as a species of Echinuria was transferred to Desportesius, becoming Desportesius longevaginatus (Molin, 1860) Wong, Anderson \& Bartlett, 1986. Thus, up to the present, there have been no species of Echinuria collected from autochthonous anatids either in Brazil or South America.

The nematodes found in $N$. peposaca were determined as belonging to the genus Echinuria and identified as E. uncinata by the following characters: anterior region with four cordons not recurrent, but anastomosed posteriorly; cuticle with four lateral rows of longitudinal spines along the entire length of the body; males with unequal and dissimilar spicules; right spicule with two conical or spike-like projections and a trans-

Revista Brasileira de Zoologia 23 (2): 520-528, junho 2006 

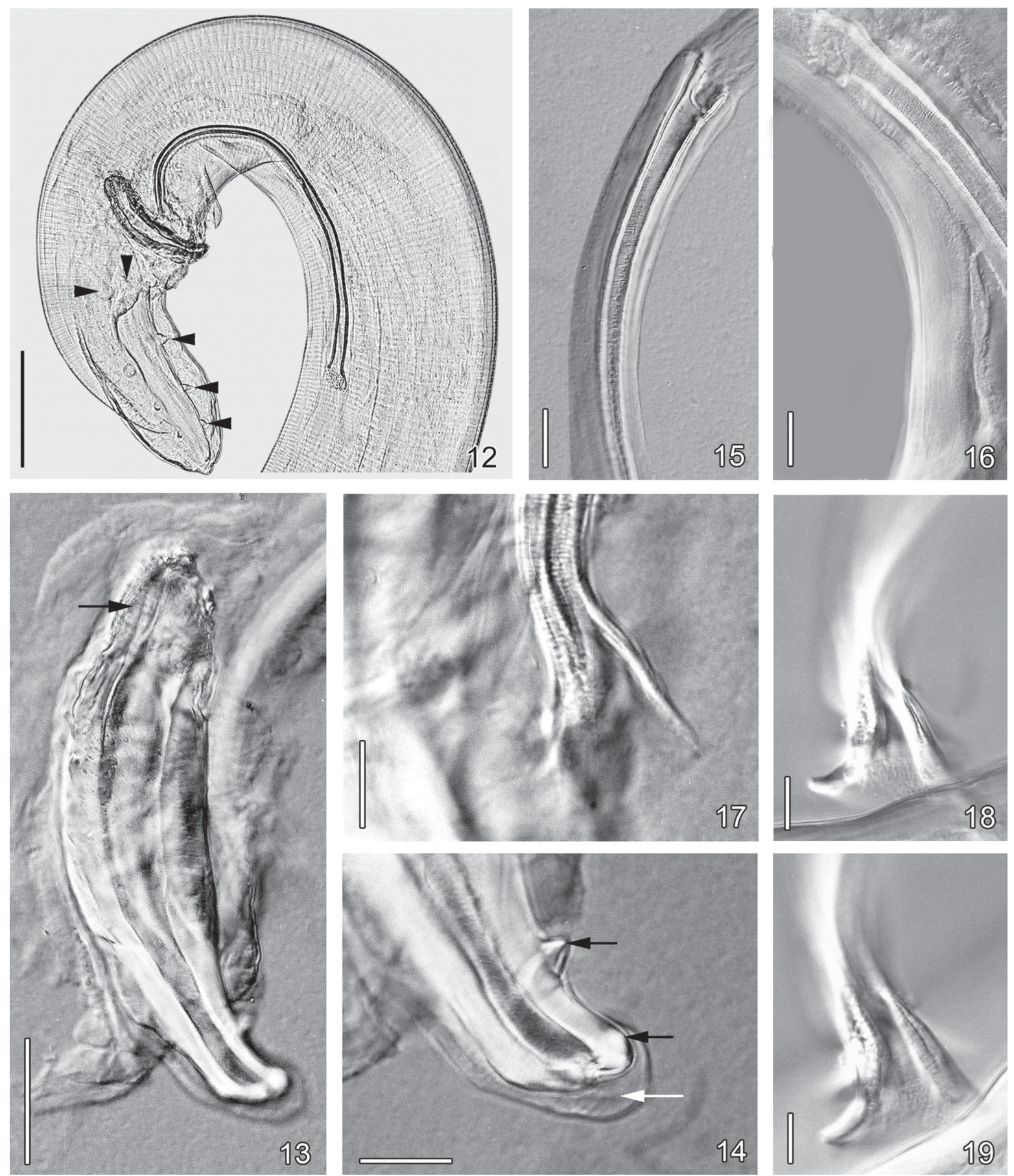

Figures 12-19. Posterior region of male Echinuria uncinata: (12) showing five pairs of post-cloacal papillae (head arrows pointing one papilla of each pair), bar $=250 \mu \mathrm{m} ;(13)$ right spicule $(D I C)$, proximal region showing fine granules $($ arrow $)$, bar $=50 \mu \mathrm{m} ;(14)$ right spicule (DIC), showing conical or spike-like projections (larger spike and smaller spike-black arrows) and transparent membrane (white arrow) bar = 50; (15) proximal extremity of left spicule (DIC), bar = $30 \mu \mathrm{m}$; (16) proximal extremity of left spicule, another view (DIC), bar $=25 \mu \mathrm{m}$; (17) distal extremity of left spicule, showing the flared, three pointed distal end (DIC), bar = 20 $\mu \mathrm{m}$; (18) distal extremity of left spicule, showing the flared, thin-walled, open funnel-like tip (DIC), in a different position, bar = 25 $\mu$ m; (19) distal extremity of left spicule, showing the flared, thin-walled, open funnel-like tip (DIC), another position, $b a r=20 \mu \mathrm{m}$.

Revista Brasileira de Zoologia 23 (2): 520-528, junho 2006 

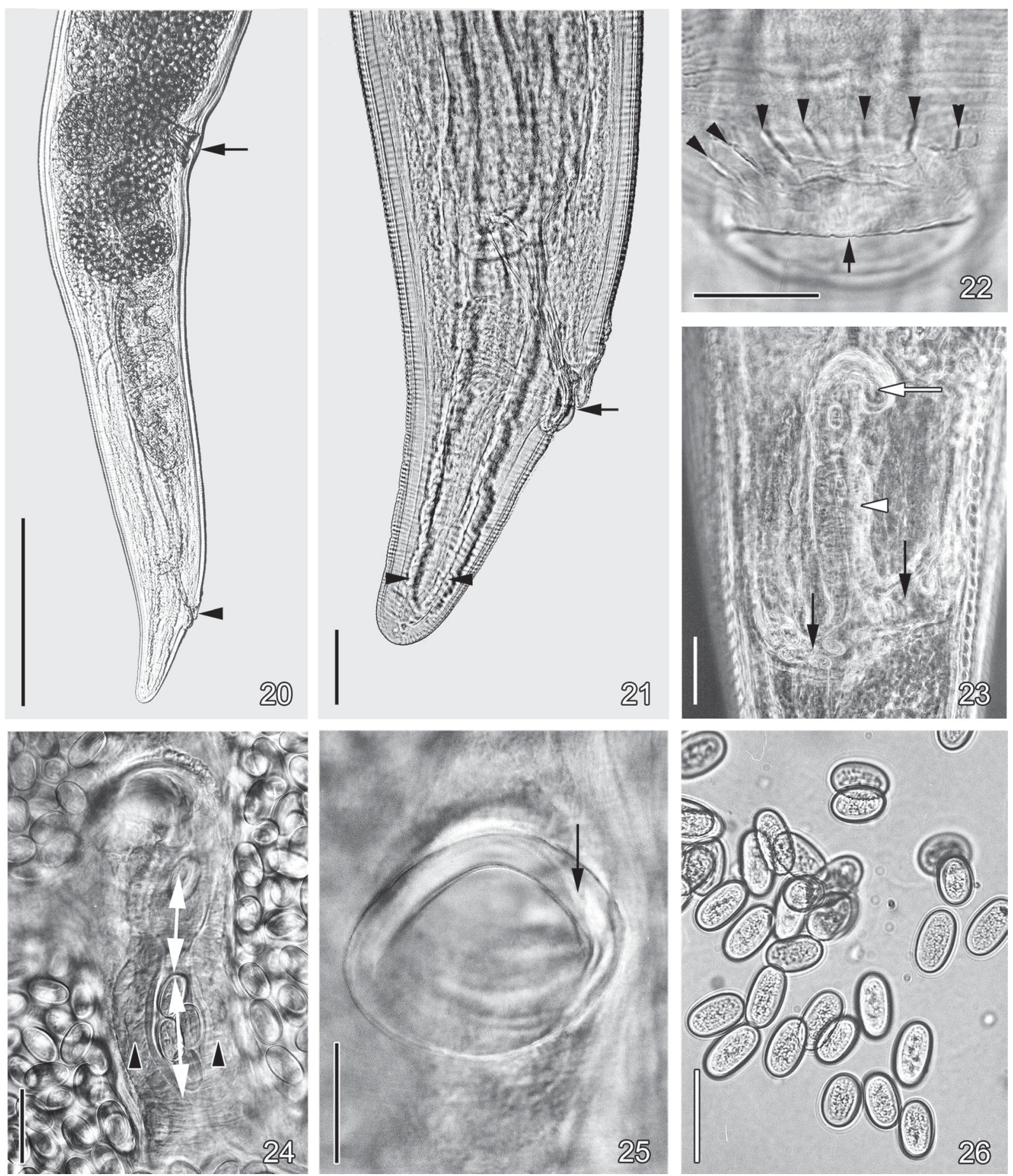

Figures 20-26. Posterior region of adult female Echinuria uncinata: (20) vulva (black arrow) and anus (black head arrow), bar = $250 \mu \mathrm{m}$; (21) caudal region showing anus (black arrow) and the lateral rows of cuticular spines meeting almost at the tip of body (black head arrows), bar = $50 \mu \mathrm{m}$; (22) anus, a horizontal slit-like opening (arrow) with series of 'thickenings' anteriorly (head arrows) (DIC), bar = $50 \mu \mathrm{m}$; (23) vulva (white arrow), muscular vagina (head arrow), and the two uteri joining the vagina (black arrows), bar = 100 $\mu \mathrm{m}$; (24) muscular vagina (double headed white arrows) with eggs, showing its thick walls (black head arrows) $(\mathrm{DIC}), \mathrm{bar}=10 \mu \mathrm{m} ;(25) \mathrm{vulva}$ with thick border (arrow) (DIC), bar $=50 \mu \mathrm{m}$; (26) thick-shelled, elliptical eggs, bar $=50 \mu \mathrm{m}$.

Revista Brasileira de Zoologia 23 (2): 520-528, junho 2006 
parent membrane, in the distal area, which, according to Clark (1979) is characteristic of this species; and, females with the vulva in the posterior region of the body.

In the present work, the total length of males of $E$. uncinata found $N$. peposaca varied from 9.4-12.3 mm. CRAM (1927) recorded males with $8-10 \mathrm{~mm}$ in length, while BEzUвIк (1956) reported males with 7-9 $\mathrm{mm}$ in length, from the United States and Poland, respectively. Austin \& WeLch (1972) recorded males 4.35-9.75 mm long, in Canada; while McDonald (1974) indicated a length variation of $8-12.8 \mathrm{~mm}$. Females of E. uncinata varied from 12.7-15.6 $\mathrm{mm}$ in length, which is well within the range (12-20.5 mm) given by McDonALD (1974), but smaller than the measurements (12-18.5 mm) given by CrAm (1927), and larger than that $(10.57 \mathrm{~mm})$ recorded by Austin \& WelCH (1972). The structure of cordons observed in the specimens of the present work (Fig. 5) was similar to that described by KeNNEDY et al. (1973) seen with light microscopy and with SEM, being formed by curved plates with a median canal, slightly irregular at the point of anastomosis.

Echinuria uncinata has been cited as a species highly pathogenic to anatid birds (CoRnwell 1963, Austin \& Welch 1972, Work et al. 2004, among others, including many reports in the Russian literature). In the present study such a condition has not been observed. Overall prevalence was low (3.8\%), but the species was present in two disjunct sampling areas along the migratory flyway of this bird: a. - the coastal region of the State of Rio Grande do Sul, where the rosy-billed pochards spend the winter - wintering grounds, and, b. - the northern region of Argentina - one of the breeding grounds. Low prevalence of E. uncinata has also been found by FedyNich et al. (1996) in two allopatric populations (Florida -2 of $20=10 \%$ and Texas -1 of $20=5 \%$ ) of $A$. fulvigula, a nonmigratory anatid. These authors also found low intensities of infection (Florida -5 and 6 and Texas -2), as it is reported in the present work. According to Work et al. (2004), this nematode can cause significant mortalities in bird populations under stress, such as drought, in which case birds would concentrate in small water collections, thus increasing the chance of being exposed to infected intermediate hosts. Apparently this has not been the case either in the study of FEDYNICH et al. (1996) or in the present study.

Austin \& Welch (1972) indicated that the age of the host may play a role in the susceptibility to parasitism, the older ducks being more resistant to infection, as were the birds in the present work. These authors found numerous worms and granulomas in five eider ducklings (Somateria mollissima Linnaeus, 1758), which died, and suggested that it was indicative of a high degree of susceptibility due to the age of the birds. These authors also conducted experiments using several species of anatids and found that: "all granulomas were located along the isthmus between the proventriculus and gizzard except in the domestic geese", where the nematodes were found also at the junction of the esophagus and the proventriculus, as found in the present work.
In the present study the granulomas were limited to the proximal esophagus, almost at the junction with the proventriculus (Figs 1 and 2). The restriction to the proximal esophagus without infecting the proventriculus, gizzard, and the proximal portion of the duodenum could be related to the low intensities of infection found, which, in turn, could be due to the fact that the ducks now examined belonged to wild flocks, not confined to zoos or bird sanctuaries, as it was recorded in the majority of the previous published reports. This might be an indication that birds in free ranges can act as natural reservoires for the parasite that in ecologically stable environments may not represent great threat to wild populations, as CRAM (1925) had already suggested. The fact that up to now there have been no records of domesticated anatids infected by any species of Echinuria in South America may mean that, at least in Brazil, bird mortalities are not usually officially reported.

\section{ACKNOWLEDGEMENTS}

To IBAMA, for the permission to capture the hosts; to João O. Meneghetti, Departamento de Zoologia, Instituto de Biociências, UFRGS, for the constant counseling on bird matters; Jorge E. de A. Mariath and Rinaldo P. dos Santos, Laboratório de Anatomia Vegetal, Instituto de Biociências, UFRGS, making available to us the Leica DMR Hc Differential Interference Contrast (DIC) microscope. To Samantha A. Seixas, Cassandra de M. Monteiro, and Luiz C.C. Daudt for their special cooperation in the laboratory; to Jair Nunes and Sidnei A. Bavaresco for collecting the ducks; to João Amintas Maciel and Simone de Arruda Gomes for their special kindness of allowing us to stay in their property (Fazenda Sossego), Municipality of Santa Vitória do Palmar.

\section{REFERENCES}

Amato, J.F.R.; W.A. Boeger \& S.B. Amato. 1991. Protocolos para laboratório: coleta e processamento de parasitos de pescado. Seropédica, Gráfica da Universidade Federal Rural do Rio de Janeiro, 81p.

Aмato, J.F.R.; S.B. Амato \& L.C.C. Daudt. 2003. New species of Temnocephala Blanchard Platyhelminthes, Temnocephalida) ectosymbiont on Aegla serrana Buckup \& Rossi (Crustacea, Anomura) from southern Brazil. Revista Brasileira de Zoologia, Curitiba, 20 (3): 493-500.

Austin, F.G. \& H.E. Welch. 1972. The occurrence, life cycle, and pathogenicity of Echinuria uncinata (Rudolphi, 1819) Soloviev, 1912 (Spirurida, Nematoda) in waterfowl at Delta, Manitoba. Canadian Journal of Zoology, Ottawa, 50: 385-393.

AverY, R.A. 1966a. Helminth parasites of wildfowl from Slimbridge, Gloucestershire. I. Parasites of captive Anatidae. Journal of Helminthology, Wallingford, 40 (3/4): 269-280.

AverY, R.A. 1966b. Helminth parasites of wildfowl from Slimbridge, Gloucestershire. II. Parasites of wild mallard. Journal of Helminthology, Wallingford, 40 (3/4): 281-284.

Revista Brasileira de Zoologia 23 (2): 520-528, junho 2006 
Bezubik, B. 1956. Helmintofauna dzikich kaczek (podrodz. Anatinae). Acta Parasitologica Polonica, Warsaw, 4 (3): 407-510.

Bush, A.; K.D. Lafferty; J.M. Lotz \& A.W. Shostak. 1997. Parasitology meets ecology on its own terms: Margolis et al. Revisited. Journal of Parasitology, Lawrence, 83: 575-583.

Buxton, J.C.; C.M. Ford \& I.B. MunRo. 1952. Infestation of domestic ducks with Acuaria (Echinuria) uncinata. The Veterinary Record, London, 64 (1): 5-6.

Chandraserharan, K. \& C.T. Peter. 1969. Studies on the common nematodes of domestic ducks (Anas platyrhynchos domesticus) - Correspondence. The Indian Veterinary Journal, Chennai, 46: 454.

Chitwood, B.G. \& E.E. WeHr. 1934. The value of cephalic structure as characters in nematode classification, with special reference to the superfamily Spiruroidea. Zeitschrift für Parazitenkunde, Jena, 7: 273-335.

CLARK, W.C. 1977. New Zealand grey duck a new host for Echinuria uncinata (Nematoda: Acuariidae) - Correspondence. New Zealand Veterinary Journal, Wellington, 25: 39.

Clark, W.C. 1979. Echinuria australis sp. nov. and E. uncinata (Nematoda: Spirurida), parasites of ducks in New Zealand. New Zealand Journal of Zoology, Wellington, 6: 7-12.

Cornwell, G. 1963. Observations on waterfowl mortality in southern Manitoba caused by Echinuria uncinata (Nematoda, Acuariidae). Canadian Journal of Zoology, Ottawa, 41: 699703.

Cram, E.B. 1925. New records of economically important nematodes in birds. Journal of Parasitology, Lawrence, 12 (2): 113-114.

Cram, E.B. 1927. Bird Parasites of the Nematode Suborders Strongylata, Ascaridata, and Spirurata. United States National Museum Bulletin, Washington, 140: XVIII+456p.

Cram, E.B. 1928. Nematodes of pathological significance found in some economically important birds in North America. United States Department of Agriculture Technical Bulletin, Washington, 49: 1-9.

FARIAS, J.D. \& A.G. CANARIs. 1986. Gastrointestinal helminths of the Mexican duck, Anas platyrhyncos diazi Ridgeway, from North Central Mexico and southwestern United States. Journal of Wildlife Diseases, Lawrence, 22 (1): 51-54.

Fedynich, A.M.; D.B. Pence; P.N. Gray \& J.F. Bergan. 1996. Helminth community structure and pattern in two allopatric populations of a nonmigratory waterfowl species (Anas fulvigula). Canadian Journal of Zoology, Ottawa, 73: 1253-1259.
George, R.R. \& E.G. Bolen. 1975. Endoparasites of black-bellied whistling ducks in southern Texas. Journal of Wildlife Diseases, Lawrence, 11: 17-22.

GibSON, E.A. \& E.G. BARNES. 1957. Acuaria uncinata infestation in domestic geese and ducks. The Veterinary Record, London, 69: 754-756.

Humason, G.L. 1972. Animal Tissue Techniques. San Francisco, W.H. Freeman and Company, 641p.

Jansen JR., J. \& E. van den Broek. 1963. Parasites of zoo-animals in the Netherlands and of exotic animals II. Bijdragen tot de Dierkunde, Amsterdam, 36: 65-68.

Kennedy, E.; H.E. Welch \& T.A. Dick. 1973. Cordon and spine ultrastructure of the waterfowl parasite Echinuria uncinata (Rudolphi, 1819) Soloviev 1912 (Spirurida: Nematoda). Canadian Journal of Zoology, Ottawa, 51: 1133-1137.

Lalitha, C.M. \& V.S. Alwar. 1960. Parasites of domestic ducks (Anas boschas domesticus) in Madras (A preliminary note). The Indian Veterinary Journal, Chennai, 38: 179-181.

Lone, M.H.; V.S. Alwar \& C.M. Lalitha. 1971. Studies on helminth of domestic ducks in Madras. The Indian Veterinary Journal, Chennai, 49: 543-545.

McDonald, M.E. 1974. Key to the nematodes reported in waterfowl. Washington, Department of the Interior, Bureau of Fisheries and Wildlife Resource Publication 122, 44p.

Ould, P. \& H.E. Welch. 1980. The effect of stress on the parasitism of mallard ducklings by Echinuria uncinata (Nematoda: Spirurida). Canadian Journal of Zoology, Ottawa, 58: 228-234.

Vicente, J.J.; H. de O. Rodrigues; D.C. Gomes \& R.M. Pinto. 1995. Nematóides do Brasil. Parte IV: Nematóides de aves. Revista Brasileira de Zoologia, Curitiba, 12(1): 1-273.

Wong, P.L.; R.C. ANDERSON \& C.M. BARTlett. 1986. Revision of the genus Syncuaria Gilbert, 1927 (Nematoda: Acuarioidea). Canadian Journal of Zoology, Ottawa, 64: 1186-1196.

Work, T.M.; C.U. Meteyer \& R.A. Cole. 2004. Mortality in Laysan ducks (Anas laysanensis) by emaciation complicated by Echinuria uncinata on Laysan Island, Hawaii, 1993. Journal of Wildlife Diseases, Lawrence, 40 (1): 110-114.

ZuchowsкA, E. 1970. Echinurioza ptaków blaszkodziobych w ogrodzie zoologicznym w Lodzi. Wiadomosci Parazytologiczne, Wroclaw, 16 (2): 207-208.

ZuchowsкA, E. 1997. Helmintofauna Anseriformes (Aves) z ogrodu zoologicznego w Lodzi. Wiadomosci Parazytologiczne, Wroclaw, 43 (2): 213-221.

Received in 17.VIII.2005; accepted in 16.V.2006. 